\title{
Význam pohybových aktivit seniorek z hlediska úprav funkěního stavu svalového systému
}

\section{Importance of a seniors physical activity for adjustament of func- tional condition of their muscular system}

\author{
Wiednerová Veronika, Kopřivová Jitka, Budíková Marie \\ Fakulta sportovních studií, Př́rodovědecká fakulta, Masarykova univerzita v Brně
}

\begin{abstract}
Abstrakt:
Studie se zabývá vyšetřováním funkčního stavu svalového systému u seniorek staršich šedesáti let. Výzkum byl provádèn u záměrně vybraného souboru, u kterého byla pravidelně stimulována pohybová aktivita. Funkční stav svalového systému byl vyšetren dle Jandy (2004) a následné pohybové změny vyhodnoceny pomocí Friedmanova testu a Cohenova koeficientu věcného účinku. Na základě zaznamenaných dat můžeme v souladu $s$ dřve prokázanými poznatky konstatovat, že přiměrená pohybová intervence má významný vliv na úpravu testovaných pohybových stereotypů, na obnovení fyziologické délky testovaných svalů a svalových skupin s tendencí ke zkrácení a na obnoveni síly testovaných svalù a svalných skupin s tendencí koslabení. Toto zjištění by mohlo podpořit ideu o zařazení pohybové aktivity do každodenního života seniorů.
\end{abstract}

\begin{abstract}
:
The study deals with the investigation of functional condition of seniors' muscular system at the age of 60 and more. The research was performed with an intentionally selected file of seniors in which a physical activity was regularly stimulated. The functional condition of muscular apparatus was investigated according to Janda test (2004) and the following motoric changes were evaluated with the help of Friedman test and objective relevance. On the basis of the recorded data in accordance to previous proved findings we can state that an adequate physical intervention has a high importance for adjustment of tested motoric stereotypes, restoring physiological length of tested muscles and muscles with a tendency to shortening, and restoring strength of tested muscles and muscles with tendency to weakening. These findings might support the idea of including physical activity to seniors' everyday life.
\end{abstract}

Klíčová slova: pohybová aktivita, senioři, funkční stav pohybového aparátu

Key words: physical activity, seniors, functional condition of motoric apparatus

Úvod:

Posun hranice seniorského věku je třeba považovat za zásadní úspěch, protože tento fenomén vznikl díky delšímu životu. Na druhé straně s sebou přináší problémy, které je tř̌eba řešit. Jde zejména o to, aby se s prodloužením lidského věku prodloužilo také období, kdy je člověk schopen vést plnohodnotný a nezávislý život v dobrém zdravotním stavu. Dále se jedná o uchování či zlepšení kvality života ve vyšším věku.

Pro osoby staršího věku jsou výhody nezávislého a kvalitního života přitažlivější, než prodloužení vlastní existence. Aktivní senior, který je schopen i ve vysokém věku 90 let udržet nezávislý styl svého života, posunuje své biologické hodiny o 15 až 20 roků. Tento účinek nemá žádná dietní nebo farmakologická intervence, nýbrž pravidelná pohybová aktivita. Tělesná, duševní pohoda a dobré zdraví, které získáme na základě pravidelného cvičení, se následně projeví, jak ve spokojenosti stárnoucí populace, tak i v jejím ekonomickém zabezpečení (Stejskal, 2004).

Z řad studií vyplývá, že u seniorů je efekt pohybové intervence, která je založena na pravidelnosti a individuálních možnostech každého, velmi opodstatněný (Kawamoto et al., 2004, Brown et al., 2003, Riegerová et al., 2007, Štilec 2004). 


\section{Cíl studie:}

Cílem studie je posoudit efekt cvičebního programu z hlediska úpravy funkčního stavu svalového systému u vybrané skupiny seniorek starších šedesáti let. Pro náš výzkum stanovujeme základní a dílčí hypotézy:

\section{Základní hypotéza:}

Pravidelné provádění vybraného cvičebního programu po dobu dvou let pozitivně ovlivní úroveň funkčního stavu svalového systému ve smyslu zachování nebo zlepšení původního zjištěného stavu u vybrané skupiny seniorek.

\section{Dílčí hypotézy:}

H1a Pravidelné provádění vybraného cvičebního programu pozitivně ovlivní úroveň svalového zkrácení ve smyslu zachování nebo zlepšení původního zjištěného stavu u vybrané skupiny seniorek.

H1b Pravidelné provádění vybraného cvičebního programu pozitivně ovlivní úroveň svalového oslabení ve smyslu zachování nebo zlepšení původního zjištěného stavu u vybrané skupiny seniorek.

H1c Pravidelné provádění vybraného cvičebního programu pozitivně ovlivní úroveň pohybových stereotypů ve smyslu zachování nebo zlepšení původního zjištěného stavu u vybrané skupiny seniorek.

\section{Metodika:}

\section{Popis zkoumaného souboru:}

V souladu s výzkumným cílem práce tvoří soubor záměrně vybraná skupina 25 seniorek, ve věku 61 až 89 let. Základním požadavkem byla dobrovolná participace na výzkumu, dobrovolné podstoupení všech odborných vyšetření a schopnost samostatné chůze. Jednalo se o účast na pravidelném intervenčním programu, na základních antropometrických vyšetřeních a vyšetřeních funkčního stavu pohybového aparátu s možností spolupráce po dobu tříletého výzkumu. Zúčastněné seniorky jsou většinou lidé žijící ve vlastních domácnostech, kteří do Domova pro seniory docházejí pouze na cvičební program. Základní biometrické charakteristiky probandů zachycuje tab. 1.

Tabulka 1: Tělesná výška, tělesná hmotnost, BMI a věk testovaných žen

\begin{tabular}{|c|l|c|c|c|c|}
\hline \multicolumn{2}{|c|}{} & $\begin{array}{l}\text { Tělesná výška } \\
(\mathrm{cm})\end{array}$ & $\begin{array}{l}\text { Tělesná } \\
(\mathrm{kg})\end{array}$ & $\begin{array}{l}\text { BMI } \\
\text { hmotnost } \\
\text { váha v kg/výška } \\
\text { v m² }\end{array}$ & $\begin{array}{l}\text { Věk } \\
\text { (rok) }\end{array}$ \\
\hline \multirow{2}{*}{$\begin{array}{l}\text { ŽENY } \\
(\mathrm{n}=25)\end{array}$} & $\begin{array}{l}\text { průměr } \\
\text { smedrodatná }\end{array}$ & 159,2 & 69,8 & 27,49 & 71,0 \\
\cline { 2 - 7 } & medián & 160,5 & 10,6 & 3,77 & 7,3 \\
\hline
\end{tabular}

Poznámka: Pro lepší orientaci uvádíme kategorizaci BMI (podváha $<18.5$, přiměřená hmotnost $18.5-25$, nadváha $25-30$, obezita $>30$ )

\section{Popis intervenčního programu:}

Cvičební program pro vybrané probandy probíhal v Domově pro seniory v Brně, na ulici Vychodilově po dobu dvou let. Lekce probíhaly dvakrát týdně, doba trvání cvičební jednotky činila 60 minut. Cvičební program byl po konzultaci s odborníky vhodně nastavený a připravený, probíhal pod vedením zkušených lektorů z Fakulty sportovních studií a pod vedením rehabilitační pracovnice př́mo z Domova pro seniory. Po prvním roce cvičení bylo provedeno druhé, kontrolní měření funkčního stavu pohybového aparátu, aby mohlo dojít k následné korekci cvičebního programu.

Lekce začínala krátkým zahřátím celého pohybového aparátu, at' již v sedu na židli, či ve stoji. Následovalo zařazení uvolňovacích cvičení, která jsou velmi důležitá pro zachování či zvětšení rozsahu kloubní pohyblivosti a z hlediska ovlivnění měkkých struktur. Poté byla vložena série protahovacích cvičení zaměřená na svalstvo 
převážně posturální, tedy s tendencí ke zkrácení a série posilovacích cvičení příznivě působící na svalstvo převážně fázické, tedy s tendencí k oslabení se současným zdůrazněním na správné vykonávání pohybu z hlediska pohybových stereotypů. Na závěr cvičební lekce byla začleněna relaxace a celkové uvolnění pomocí individuální nebo kolektivní masáže se zpěvem celé cvičící skupiny seniorů. Při cvičebních lekcích bylo využito mnoho běžných cvičebních pomůcek, ale také psychomotorických. Hodiny byly doprovázeny motivační či relaxační hudbou. Průběžně byly lekce doplňovány o cvičení pro rozvoj jemné motoriky, rovnováhy a paměti.

\section{Popis výzkumného měření:}

U vybraných seniorek byl proveden funkční svalový test dle Jandy (1996) s úpravami dle Kopřivové (1993) a Beránkové (2006). Vyšetřování bylo provedeno dle následujícího postupu. Nejprve bylo provedeno vyšetření funkčního stavu svalů převážně posturálních (s tendencí ke zkrácení), následně byl zjišt’ován způsob provedení základních hybných stereotypů. Síla vybraných svalů převážně fázických (s tendencí k oslabení) byla testována současně s vyšetřováním pohybových stereotypů. Vyšetření probíhalo před rozcvičením v teplé, tiché místnosti na vyšetřovacím stole s tvrdou podložkou a to vždy stejným odborným posuzovatelem, ve stejných podmínkách a čase. Pro srovnání údajů bylo použito jednotných způsobů záznamů a názvosloví.

Pro naši práci bylo nutné vyšetřit tyto svaly a svalové skupiny $\mathrm{s}$ tendencí ke zkrácení: m. triceps surae, flexory kolenního kloubu, flexory kyčelního kloubu (m. iliopsoas, m. tensor fasciae latae, m. rectus femoris), m.quadratus lumborum, m. erector spinae, m. pectoralis major, m.trapezius (horní část), hluboké svaly šíjové. Dále jsme vyšetřili následující pohybové stereotypy: extenze v kyčelním kloubu, flexe trupu, flexe hlavy, abdukce v ramením kloubu a zkouška kliku a současně jsme vyšetřili svalovou sílu: m. gluteus maximus, m.rectus abdominis, hluboké flexory hlavy a krku, dolní fixátory lopatek.

\section{Výsledky a diskuze:}

V práci jsme se zaměřili především na změny mezi naměřenými hodnotami funkčního svalového testu u skupiny seniorek, tedy na rozdíly $\mathrm{v}$ hodnotách naměřených mezi vstupním a závěrečným měřením. V návaznosti na cíl a hypotézy studie bylo u každé seniorky vyšetřeno 10 svalů a svalových skupin s tendencí ke zkracování, 4 svaly a svalové skupiny s tendencí k ochabování a 5 pohybových stereotypů. Uvádíme změny ve svalovém funkčním testu vždy zvláště pro svaly a skupiny svalů s tendencí ke zkrácení, oslabení a pohybové stereotypy hodnocených pomocí Friedmanova testu.

Nejprve věnujeme pozornost výsledkům změn v hodnotách naměřených při testech pro svaly a svalové skupiny s tendencí ke zkrácení. Vlivem intervenčního programu došlo k pozitivním, statisticky významným úpravám na 5\% hladině významnosti ve smyslu optimalizace délky svalů u flexorů kolenního kloubu na pravé dolní končetině, m. tensor fasciae latae, m. rectus femoris, m. pectoralis major a m. erector spinae. Ke zlepšení bez statistické významnosti ve smyslu obnovení fyziologické délky svalů došlo u flexorů kolenního kloubu na levé dolní končetině, m. iliopsoas, m. trapezius a extenzorů krční páteře. Nulový efekt cvičení nacházíme u m. triceps surae na pravé dolní končetině, kde nenastala žádná změna mezi počátečním a závěrečným měřením. Mírné zhoršení shledáváme u m. triceps surae na levé dolní končetině a m. quadratus lumborum (Obr. 1). Zdůvodnění je možno hledat $\mathrm{v}$ nedokonalém provedení cviků zaměřených na tuto svalovou skupinu, $\mathrm{Z}$ důvodu náročnosti dotažení daných pohybů do požadované polohy v koordinaci s dechem. Z celkového hlediska u svalů a svalových skupin s tendencí ke zkrácení došlo u našich seniorek převážně ke zlepšení či zachování původních naměřených hodnot, což jednoznačně prokazuje pozitivní vliv intervenčního programu.

Obr. 1: Graf celkového zhoršsení a zlepšení funkčního svalového testu pro svaly a skupiny svalů s tendencí ke zkráceni mezi prvním a třetím měrením

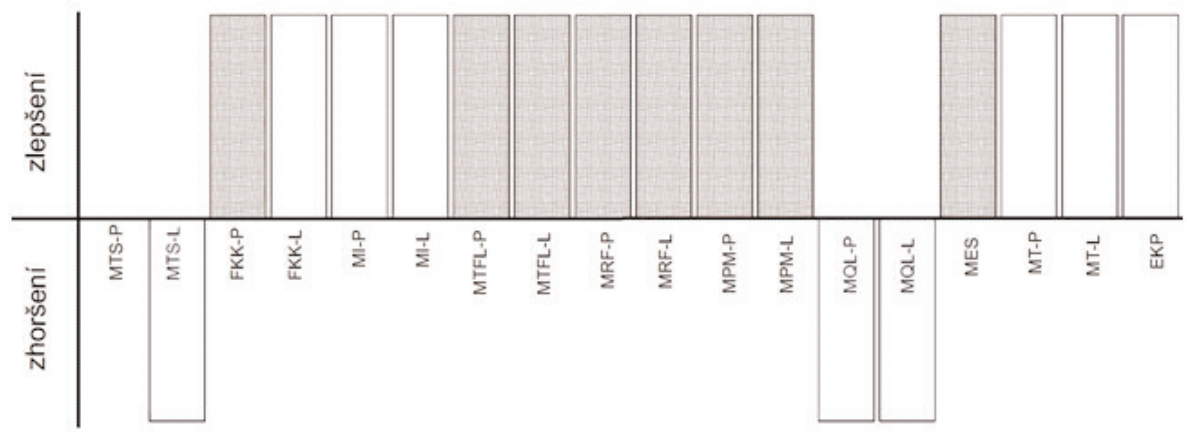




\section{Legenda:}

MTS-P/L - m. triceps surae pravá/levá, FKK-P/L - flexory kolenního kloubu pravá/levá, MI-P/L - m. iliopsoas pravá/levá, MTFL-P/L - m. tensor fasciae latae pravá/levá, MRF-P/L - m. rectus femoris pravá/levá, MPM-P/L - m. pectoralis major pravá/ levá, MQL-P/L - m. quadratus lumborum pravá/levá, MES - m.erector spinae, MT-P/L - m.trapezius pravá/levá, EKP - extenzory krční páteře

\section{zlepšení či zhoršení bez statistické významnosti statisticky významné zlepšení či zhoršení}

Dále se zabýváme výsledky změn v hodnotách naměřených při testech pro svaly a svalové skupiny s tendencí k oslabení. Vlivem intervenčního programu došlo k pozitivním, statisticky významným úpravám na $5 \%$ hladině významnosti ve smyslu obnovení svalové síly u hlubokých flexorů hlavy a krku, m. rectus abdominis a m. gluteus maximus. K nulovému efektu cvičení nebo mírnému zhoršení došlu u dolních fixátorů lopatek (Obr. 2). Příčinu můžeme shledávat v kvalitě síly již při vstupním měření, kdy většina seniorek měla velmi dobré hodnocení síly této svalové skupiny, tedy již nemohla nastat změna v pozitivním smyslu. Při celkovém pohledu na svaly a svalové skupiny s tendencí k oslabení, můžeme opět hovořit o pozitivním účinku intervenčního programu.

Obr. 2: Graf celkového zhoršení a zlepšeni funkčního svalového testu pro svaly a skupiny svalů s tendencí k oslabeni mezi prvním a třetím měrením

Legenda:

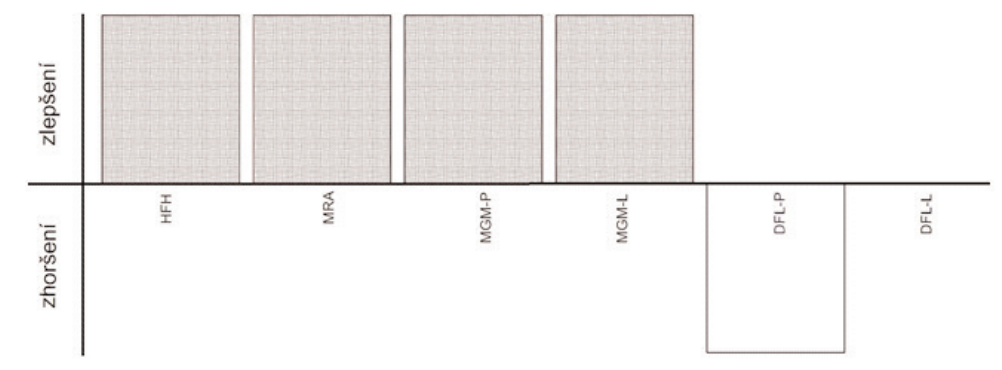

HFH - hluboké flexory hlavy a krku, MRA - m.rectus abdominis, MGM-P/L - m.gluteus maximus pravá/levá, DFL-P/L - dolní fixátory lopatek pravá/levá

\section{$\square$ zlepšení či zhoršení bez statistické významnosti \\ statisticky významné zlepšení či zhoršení}

V neposlední řadě uvádíme výsledky změn v provedení při testech pro pohybové stereotypy. Významný statistický posun na $5 \%$ hladině významnosti ve smyslu úpravy správného provedení jsme zjistili u abdukce levé horní končetiny, flexe hlavy a trupu. U pohybového stereotypu extenze dolní končetiny, jak na pravé tak levé straně došlo pouze $\mathrm{k}$ věcnému zlepšení se středním účinkem posouzeným pomocí Cohenova koefícientu. Nulový efekt cvičení a mírné zhoršení nacházíme u pohybového stereotypu abdukce pravé horní končetiny a zkoušky kliku (Obr. 3). Výsledky pohybového stereotypu zkoušky kliku korespondují s výsledky změn svalové síly dolních fixátorů lopatek, kde již uvádíme možnou příčinu zhoršení. Opět můžeme hovořit o pozitivním účinku intervenčního programu ve smyslu úprav pohybových stereotypů.

Obr. 22: Graf celkového zhoršení a zlepšeni funkčního svalového testu pro pohybové stereotypy mezi prvním a třetím měrením

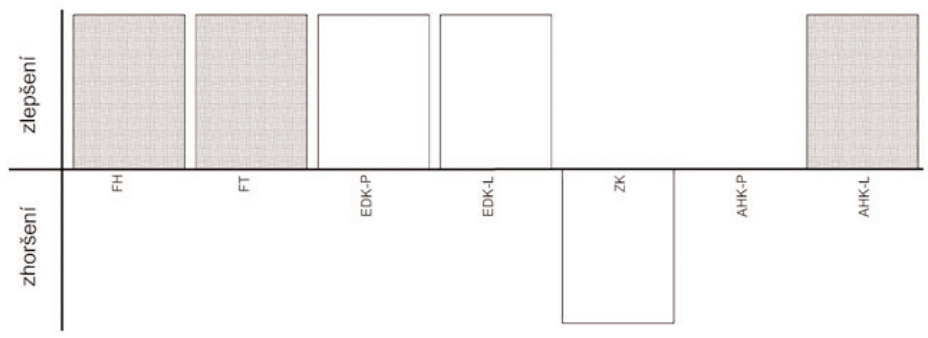




\section{Legenda:}

FH - flexe hlavy, FT - flexe trupu, EDK-P/L - extenze dolní končetiny pravá/levá, ZK - zkouška kliku, AHK-P/L - abdukce horní končetiny pravá/levá

$\square$ zlepšení či zhoršení bez statistické významnosti statisticky významné zlepšení či zhoršení

Z hlediska laterality měřených svalových testů a jejich změn v průběhu našeho výzkumu nedochází k výraznému rozdílu mezi pravou a levou stranou těla. Pokud jsme shledali u daného pohybu zhoršení/zlepšení na pravé straně těla, došlo ke zhoršení/zlepšení i na levé straně těla, diferencovanost nacházíme ve statistické významnosti či nezměněném stavu.

Náš experiment tak potvrzuje hypotézu o vlivu pohybového intervenčního programu na funkční stav pohybového aparátu ve stáří, na který poukazují ve svém výzkumu také autoři Riegerová (2010), Batista et al. (2009), Vařeková et al. (2007), Štilec (2004), Carvalho et al. (2009) a Toraman, Ayceman (2005).

\section{Závěr:}

Výsledky práce potvrzují studie jiných autorů. Je nutné pravidelně zařazovat vyrovnávací cvičení do běžných denních aktivit seniorů - přispěje ke zlepšení funkčního stavu pohybového aparátu, a tím ke zlepšení kvality života. Je třeba zdůraznit zejména pravidelnost cvičení a vhodných pohybových aktivit, aby nedošlo k retenci již upravených stereotypů. Cvičení přineslo vybraným seniorkám zlepšení funkčního stavu pohybového aparátu, a také pozitivní náladu a motivaci $\mathrm{k}$ pohybové činnosti, př́jemné pocity z dobře vykonané aktivity, umožnilo jim nové sociální kontakty.

\section{Literatura}

Batista LH, Vilar AC, de Almeida Ferreira JJ, Rebelatto JR \& Salvini TF. (2009). Active Stretching Improves Flexibility, Joint Torque, and Functional Mobility in Older Women. American Journal of Physical Medicine and Rehabilitation, 88, 10, pp. 815-822.

Beránková, L. (2006) Monitoring a analýza vzniku vertebrogenních algických stavi̊ populace středního věku se sedavým zaměstnáním. Brno: FSpS MU

Brown DW, Balluz LS, Heath GW, Moriarty DG, Ford ES, Giles WH \& Mokdad AH. (2003) Associations between recommended levels of physical activity and health-related quality of life. Findings from the 2001 Behavioral Risk Factor Surveillance System (BRFSS) survey. Preventive Medicine, 37, 5, pp. 520-528.

Carvalho MJ, Marques E \& Mota J. (2009). Training and Detraining Effects on Functional Fitness after a Multicomponent Training in Older Women. Gerontology, 55, 1, pp. 40-48.

Janda, V., Herbenová, A., Jandová, J. \& Pavlů, D. (2004). Svalové funkční testy. Praha: Grada.

Kawamoto,R., Yoshida, O. \& Oka, Y. (2004). Factors related to functional capacity in community-dwellin elderly. Geriatrics and Gerontology International, 4, 2, pp. 105-110.

Kopřivová, J. \& Kopřiva, Z. (1997). Vyrovnávací cvičení. Brno: Studio pohybových aktivit.

Riegerová, J. (2007). Úpravy svalových funkcí a držení těla u seniorek po intervenčním zásahu cíleného cvičebního programu. In H. Bednářová (Ed.), Aktivní v každém věku II: sborník př́spěvků z odborného semináre zaměreného na aplikované pohybové aktivity seniorů, Olomouc, 6. - 7. 12.2007 (pp. 59-67). Olomouc, Czechia: Univerzita Palackého.

Riegerová, J. (2010). Hýbejme se. In H. Bednářová (Ed.), Aktivní v každém věku IV: WSborník př́spěvki z odborného semináre zaměreného na aplikované pohybové aktivity seniorů, Olomouc, 2010 (pp. 43-51). Olomouc, Czechia: Univerzita Palackého.

Stejskal, P. (2004). Proč a jak se zdravě hýbat. Břeclav: Presstempus.

Štilec, M. (2004). Program aktivního stylu života. Praha: Portál.

Toraman, N. F. \& Ayceman, N. (2005). Effects of six weeks of detraining on retention of functional fitness of old people after nine weeks of multicomponent training. British Journal of Sports Medicine, 39, 8, pp. 565-568. 
STUDIA SPORTIVA 2012/6, č. 2, s. 13-18

Vařeková, R., Vařeka, I., Hnátek, J., Pišt'ková, N., \& Burianová, K. (2007). Výskyt svalových dysbalancí u pacientů léčených v Lázních Luhačovice, a. s. ve středním a seniorském věku. In J. Wittmannová (Ed.), Aktivní v každém věku: sbornik př́spěvkỉ z odborného semináre zaměreného na aplikované pohybové aktivity seniorů, Olomouc, 2007, (pp. 77-80). Olomouc, Czechia: Univerzita Palackého. 